\title{
Analisis Regresi Komponen Utama Robust dengan Metode Minimum Covariance Determinant - Least Trimmed Square (MCD-LTS)
}

\author{
Siska Diah Ayu Larasati ${ }^{1}$, Khoirin Nisa ${ }^{1, *}$ dan Eri Setiawan ${ }^{1}$ \\ ${ }^{1}$ Jurusan Matematika, Fakultas MIPA, Universitas Lampung \\ J1. Soemantri Brojonegoro 1 Bandar Lampung \\ *Email korespondensi: khoirin,nisa@ fmipa.unila.ac.id \\ Dikirim: 27-02-2020, Diterima: 17-03-2020, Diterbitkan: 31-03-2020
}

\begin{abstract}
Abstrak
Regresi Komponen Utama (RKU) merupakan metode yang digunakan untuk mengatasi masalah multikolinearitas dengan mereduksi dimensi variabel bebas sehingga diperoleh variabel baru yang lebih sederhana tanpa kehilangan sebagian besar informasi yang terkandung pada variabel bebasnya. Apabila pada data pengamatan terindikasi adanya pencilan, maka diperlukan metode yang tegar terhadap pencilan yaitu metode RKU robust. Dalam paper ini kami menggunakan metode robust yang merupakan kombinasi antara Analisis Komponen Utama Robust dengan metode Minimum Covariance Determinant (MCD) dan Analisis Regresi Robust dengan metode Least Trimmed Square (LTS). Tujuan dari penelitian ini adalah mengkaji analisis RKU robust dengan metode MCD-LTS serta mengetahui ketegaran RKU robust dengan melihat kepekaannya terhadap pencilan. Hasil yang diperoleh dibandingkan dengan RKU klasik berdasarkan nilai bias dan Mean Square Error (MSE) pada beberapa ukuran sampel dan persentase pencilan yang berbeda. Hasil dari penelitian ini menunjukkan bahwa RKU robust menggunakan MCD-LTS efektif dan efisien dalam mengatasi masalah multikolinearitas dan pencilan pada analisis regresi.
\end{abstract}

Kata kunci : multikolinearitas, pencilan, regresi komponen utama, robust.

Abstract

Principal Component Regression (PCR) is a method used to overcome multi collinearity problems by reducing the dimensions of independent variables to obtain new simpler variables without losing most of the information contained in the variables. If the data analyzed contain outliers, a robust method on PCR is required. In this paper we use a robust method which is a combination of Robust Principal Component Analysis using the Minimum Covariance Determinant (MCD) method and Robust Regression Analysis using Least Trimmed Square (LTS) method. The purpose of this study is to examine the robust PCR analysis using the MCD-LTS method and to know the robustness of the method by looking at its sensitivity to outliers. Results for this purpose we compared the MCD-LTS PCR to the classic PCR based on the bias and Mean Square Error (MSE) values on several different sample sizes and percentages of outliers. The results of this study indicate that robust PCR using MCD-LTS is effective and efficient in overcoming the problem of multicollinearity and outliers in regression analysis.

Keywords: multicollinearity, outliers, principal component regression, robust.

\section{Pendahuluan}

Analisis regresi merupakan salah satu metode analisis data yang digunakan untuk menyelidiki hubungan antara variabel respon dengan satu atau beberapa variabel bebas. Apabila hubungan yang diselidiki terdiri dari satu variabel respon dan satu variabel bebas maka disebut dengan analisis regresi linear sederhana. Sedangkan analisis regresi linear berganda terdiri dari satu variabel respon dan lebih dari satu variabel bebas. Bentuk persamaan regresi dalam bentuk variabel asal $X$ dapat ditulis sebagai berikut:

$$
Y=\beta_{0}+\beta_{1} X_{1}+\ldots+\beta_{p} X_{p}+\varepsilon
$$

dengan $Y$ merupakan variabel tak bebas, $X_{j}$ variabel bebas ke-j $(j=1,2, \ldots, p), \beta_{0}$ dan $\beta_{j}$ adalah parameterparameter regresi, dan $\varepsilon$ merupakan galat. 
Permasalahan yang sering dihadapi dalam analisis regresi linear berganda yaitu adanya multikolinearitas. Masalah ini terjadi ketika adanya korelasi yang kuat antara variabel bebas. Hal ini dapat menyebabkan $\mathbf{X}^{\mathbf{T}} \mathbf{X}$ memiliki kondisi buruk (ill condition) atau hampir singular yang pada akhirnya akan menyebabkan nilai penduga ragam bagi parameter regresi menjadi lebih besar [1].

Salah satu metode statistik yang digunakan untuk mengatasi masalah multikolinearitas adalah regresi komponen utama (RKU). Pada RKU klasik terdapat dua tahap yaitu komponen utama dibentuk menggunakan vektor eigen dari matriks kovarian sampel (S) klasik dan diregresikan terhadap Y dengan metode kuadrat terkecil [2]. Variabel baru sebagai komponen utama (Q) adalah hasil transformasi dari variabel asal (X) yang modelnya dalam bentuk matriks yaitu $\boldsymbol{Q}=\boldsymbol{A} \boldsymbol{X}$, dan komponen utama ke-j ditulis:

$$
\begin{aligned}
Q_{j} & =a_{1 j} X_{1}+a_{2 j} X_{2}+\cdots+a_{j p} X_{p} \\
& =\boldsymbol{a}_{\boldsymbol{j}}^{\boldsymbol{T}} \boldsymbol{X}
\end{aligned}
$$

dimana vektor pembobot $\boldsymbol{a}_{j}^{\boldsymbol{T}}$ diperoleh dengan memaksimumkan keragaman komponen utama ke-j, yaitu $\boldsymbol{S}_{\boldsymbol{Q}_{j}}^{\mathbf{2}}=$ $\boldsymbol{a}_{j}^{\boldsymbol{T}} \boldsymbol{S} \boldsymbol{a}_{j}$ dengan kendala $\boldsymbol{a}_{j}^{\boldsymbol{T}} \boldsymbol{a}_{\boldsymbol{j}}=1$ serta $\boldsymbol{a}_{\boldsymbol{l}}^{\boldsymbol{T}} \boldsymbol{a}_{\boldsymbol{j}}=0$, untuk $l \neq j$. Vektor pembobot $\boldsymbol{a}_{\boldsymbol{j}}^{\boldsymbol{T}}$ diperoleh dari matriks kovarian $\boldsymbol{\Sigma}$ yang diduga dengan matriks $\boldsymbol{S}$, yaitu $\boldsymbol{S}=\frac{1}{n-1} \sum_{i=1}^{n}\left(\boldsymbol{x}_{\boldsymbol{i}}-\overline{\boldsymbol{x}}\right)\left(\boldsymbol{x}_{\boldsymbol{i}}-\overline{\boldsymbol{x}}\right)^{T}$. Vektor $\boldsymbol{a}_{\boldsymbol{j}}^{\boldsymbol{T}}$ yang memenuhi kendala diatas adalah vektor eigen dari matriks kovarian $\boldsymbol{\Sigma}$. Model regresi komponen utama dapat ditulis sebagai berikut:

dengan $k \leq p$.

$$
Y=\beta_{0}+\beta_{1} Q_{1}+\ldots+\beta_{k} Q_{k}+\varepsilon
$$

Analisis RKU seperti di atas sangat sensitif terhadap pencilan (outliers) dan akan menghasilkan dugaan parameter yang bias akibat terpengaruh oleh data pencilan. Untuk itu maka diperlukan metode yang tegar terhadap pencilan yang disebut sebagai metode robust. Penelitian yang berkaitan dengan RKU robust telah dilakukan oleh para peneliti, diantaranya dapat dilihat pada [3-5].

Salah satu metode RKU robust untuk mengatasi masalah multikolinieritas dan sekaligus pencilan yaitu dengan menggunakan matriks kovarian robust pada analisis komponen utama dan metode regresi robust pada tahap analisis regresi. Salah satu metode robust bagi matriks kovarian sampel (S) yaitu metode MCD [6] dan kemudian hasil komponen-komponen utama robust yang terbentuk akan diregresikan dengan variabel respon menggunakan metode regresi robust Least Trimmed Square (LTS).

Penduga MCD adalah pasangan $(\overline{\boldsymbol{X}}, \boldsymbol{S})$, dimana $\overline{\boldsymbol{X}}$ adalah vektor rata-rata dan $\boldsymbol{S}$ adalah matriks kovariansi yang meminimumkan nilai determinan $S$ pada subsampel yang berisikan tepat sebanyak $h$ anggota dari $n$ pengamatan, dimana nilai standar dari $h=[(n+k+1) / 2]$. Pada populasi dengan jumlah pengamatan yang kecil, penduga MCD dapat dengan cepat dihitung dan ditemukan. Tetapi jika jumlah pengamatan besar, maka akan banyak sekali kombinasi subsampel dari $H$ yang harus ditemukan dan penghitungan pun akan cukup memakan waktu. Dalam mengatasi keterbatasan ini, maka digunakan suatu algoritma baru untuk metode MCD yang dinamakan dengan metode fast-MCD [7-8].

Langkah-langkah penduga MCD dalam menduga nilai koefisien regresi dengan menggunakan fast-MCD dimulai dengan mengambil subsampel pertama dari data pengamatan secara acak, misalkan subsampel tersebut $H_{1}$ dengan jumlah elemen sebanyak $h$. Selanjutnya menghitung vektor rata-rata $\overline{\boldsymbol{X}}_{M C D}$ dan matriks kovarians $\boldsymbol{S}_{M C D}$ dari $H_{1}$ dengan memisalkan $\overline{\boldsymbol{X}}_{1}$ dan $\boldsymbol{S}_{1}$ menggunakan persamaan berikut

$$
\begin{aligned}
\overline{\boldsymbol{X}}_{M C D} & =\frac{1}{h} \sum_{i \in H} \boldsymbol{x}_{\boldsymbol{i}}, \boldsymbol{x}_{\boldsymbol{i}} \text { merupakan vektor pengamatan ke- } i \\
\boldsymbol{S}_{M C D} & =\frac{1}{h} \sum_{i \in H}\left[\boldsymbol{x}_{\boldsymbol{i}}-\overline{\boldsymbol{X}}_{M C D}\right]\left[\boldsymbol{x}_{\boldsymbol{i}}-\overline{\boldsymbol{X}}_{M C D}\right]^{T}
\end{aligned}
$$

Jika $\operatorname{det}\left(\boldsymbol{S}_{1}\right)=0$, maka berhenti. Namun apabila $\operatorname{det}\left(\boldsymbol{S}_{1}\right) \neq 0$, maka dilanjutkan dengan menghitung jarak robust (robust distance $=\mathrm{RD}$ ) untuk setiap pengamatan yang kemudian diurutkan dari yang terkecil hingga terbesar menggunakan persamaan berikut

$$
R D_{i}=\sqrt{\left(\boldsymbol{x}_{i}-\overline{\boldsymbol{X}}_{M C D}\right)^{T} \boldsymbol{S}_{M C D}^{-1}\left(\boldsymbol{x}_{i}-\overline{\boldsymbol{X}}_{M C D}\right)}
$$

Pada kasus subsampel selanjutnya, yaitu $H_{2}$ akan diambil sebanyak $h$ pengamatan dengan jarak RD terkecil. Demikian seterusnya hingga mencapai konvergen $\left(S_{i+1}\right)=\left(S_{1}\right)$. Selanjutnya memilih himpunan $H$ yang memiliki determinan $\boldsymbol{S}_{M C D}$ terkecil, serta mencari $\overline{\boldsymbol{X}}_{M C D}$ dan $\boldsymbol{S}_{M C D}$ dari himpunan $H$ terpilih. 
Metode LTS menduga koefisien regresi dari data yang mengandung pencilan dengan meminimumkan jumlah kuadrat galat terhadap sebaran data yang sudah terpangkas (trimmed) yang sering juga disebut dengan istilah "sebaran terwinsorkan" (winsorized distribution) [9]. Metode ini menduga koefisien regresi dengan menggunakan metode Ordinary Least Square (OLS) terhadap subhimpunan data berukuran $h$, yaitu:

dengan $\frac{(3 n+k+1)}{4} \leq h \leq n$.

$$
\begin{aligned}
\widehat{\beta} & =\underset{\beta}{\arg \min }\left(\sum_{i=1}^{h} e_{i}^{2}\right) \\
& =\underset{\beta}{\arg \min }\left(\sum_{i=1}^{h}\left(y_{i}-\hat{y}_{i}\right)^{2}\right)
\end{aligned}
$$

Solusi $\hat{\beta}$ pada Persamaan (7) dapat diperoleh dengan menggunakan konsep turunan seperti pada penyelesaian pendugaan metode OLS. Lain halnya pada LTS, persamaan tersebut dihitung pada subhimpunan $H$ terbaik yang dilakukan dengan menggunakan algoritma resampling dari seluruh kemungkinan subhimpunan yang dapat dibentuk yaitu sebanyak $\left(\begin{array}{l}n \\ h\end{array}\right)$. Subhimpunan $H$ yang diperoleh merupakan sebaran data yang sudah terpangkas [10].

Dalam paper ini akan disajikan analisis RKU Robust dengan metode MCD-LTS serta mengkaji ketegaran metode tersebut terhadap pencilan melalui simulasi data.

\section{Metodologi Penelitian}

Data yang digunakan dalam penelitian ini merupakan data simulasi. Pada simulasi dibangkitkan data menggunakan software SAS 9.4 dengan variabel bebas $X$ sebanyak enam variabel $(k=6)$ dan galat berdistribusi normal $N(0,1)$ sehingga $Y$ merupakan kombinasi linear dari $k$ variabel bebas ditambah galat. Masing- masing data dibangkitan dengan ukuran sampel $(n=20,60,100,200)$ serta 5 jenis persentase pencilan $(5 \%, 10 \% 15 \%$, $20 \%$, 25\%) dan diulang sebanyak 1000 kali. Kemudian pencilan dibangkitkan dari distribusi normal dengan mean 50 dan simpangan baku 0,05 yaitu $\varepsilon^{*} \sim N\left(50,(0.05)^{2}\right)$.

Untuk mendapatkan data kolinearitas pada setiap himpunan data, $X_{i k}$ dibangkitkan menggunakan simulasi Monte Carlo berdasarkan McDonald \& Galarneau [11] dengan persamaan sebagai berikut:

dimana $: i=1,2, \ldots, n$ dan $j=1,2, \ldots, p$

$$
X_{i j}=\left(1-\rho^{2}\right)^{\frac{1}{2}} x_{i j}+\rho x_{i(p+1)}
$$

Di sini $x_{i 1}, x_{i 2}, \ldots, x_{i(p+1)}$ merupakan data yang dibangkitkan berdistribusi normal $N(0,1)$ dan $\rho$ ditentukan sehingga korelasi antarvariabel bebas diberikan oleh $\rho^{2}$. Dua himpunan dari variabel yang saling berkorelasi dalam artikel ini dibuat berdasarkan nilai $\rho=0.99$.

Adapun tahapan simulasi data yang dilakukan adalah sebagai berikut:

1. Membangkitkan matriks data.

2. Melakukan regresi komponen utama klasik dengan langkah sebagai berikut:

a. Menghitung matriks kovarian dari variabel asal $(X)$.

b. Menghitung nilai eigen $\lambda_{i}$ dan vektor eigen $\boldsymbol{a}_{i}$ dari matriks kovarian.

c. Menghitung skor komponen utama $Q$.

d. Memilih komponen utama yang berpadanan dengan nilai eigen terbesar.

e. Menghitung nilai duga koefisien regresi komponen utama berdasarkan komponen yang terpilih dengan metode OLS, simpan sebagai $\hat{\beta}_{j}^{(0)}$, untuk $j=0,1$.

3. Membangkitkan sebuah matriks noise dari distribusi $N\left(0,(0.01)^{2}\right)$.

4. Membangkitkan matriks pencilan dari distribusi $N\left(50,(0.05)^{2}\right)$ sehingga diperoleh matriks kontaminasi. Elemen dari matriks kontaminasi adalah nol kecuali untuk beberapa elemen yang dijadikan pencilan.

5. Menambahkan matriks noise dan matriks kontaminasi pada data simulasi. Sehingga diperoleh matriks data yang telah terkontaminasi pencilan.

6. Melakukan regresi komponen utama klasik seperti langkah 2 pada data yang telah terkontaminasi pencilan.

7. Menyimpan nilai $\hat{\beta}_{j}^{(s)}$ untuk $j=0,1$ pada regresi komponen utama klasik di langkah 6 .

8. Melakukan regresi komponen utama robust dengan langkah sebagai berikut:

9. Menghitung matriks kovarian MCD dari data yang terkontaminasi pencilan.

10. Menghitung nilai eigen $\lambda_{i}$ dan vektor eigen $a$ dari matriks kovarian MCD.

a. Menghitung skor komponen utama $Q$.

b. Memilih komponen utama yang memiliki nilai eigen lebih dari 1 . 
c. Menghitung nilai duga koefisien regresi komponen utama berdasarkan komponen yang terpilih dengan Least Trimmed Square (LTS).

11. Menyimpan nilai $\hat{\beta}_{j}^{(s)}$ untuk $j=0,1$ pada regresi komponen utama robust.

12. Ulangi langkah 4 sampai 10 sebanyak 1000 kali untuk seluruh ukuran data.

13. Menghitung nilai bias dan Mean Square Error (MSE) dari RKU klasik dan RKU robust dengan menggunakan rumus sebagai berikut:

$$
\operatorname{Bias}\left(\hat{\beta}_{j}\right)=\frac{1}{m} \sum_{i=1}^{m}\left|\hat{\beta}_{i j}^{(s)}-\hat{\beta}_{j}^{(0)}\right|, \quad \operatorname{MSE}\left(\hat{\beta}_{j}\right)=\frac{1}{m} \sum_{i=1}^{m}\left(\hat{\beta}_{i j}^{(s)}-\hat{\beta}_{j}^{(0)}\right)^{2}
$$

dimana, $j=0,1$ dan $m=1000$.

14. Membandingkan RKU robust dengan RKU klasik berdasarkan nilai rata-rata bias dan rata-rata MSE dari seluruh dugaan koefisien regresi yang dihasilkan.

\section{Hasil dan Pembahasan}

\subsection{Analisis Regresi Komponen Utama Robust}

RKU klasik membentuk komponen utama menggunakan vektor eigen dari matriks kovarian klasik yang kemudian diregresikan menggunakan metode OLS. Metode RKU klasik tanpa pencilan menjadi acuan sebagai nilai koefisien RKU sebenarnya, sedangkan RKU klasik dengan pencilan menjadi acuan untuk mengetahui tingkat ketegaran RKU robust.

Variabel $Q_{1}, Q_{2}, \ldots, Q_{j}$ disebut komponen utama dari X. Jika matriks kovarian dari variabel asal $X_{j}, j=$ $1,2, \ldots, p$ dilambangkan dengan $\boldsymbol{\Sigma}$, maka diperoleh varian komponen utama yaitu:

$$
\begin{aligned}
\operatorname{var}\left(Q_{j}\right) & =E\left[\left(Q_{j}-E\left(Q_{j}\right)\right)\left(Q_{j}-E\left(Q_{j}\right)\right)^{T}\right] \\
& =E\left[\left(\boldsymbol{a}_{j}^{\boldsymbol{T}} \boldsymbol{X}-E\left(\boldsymbol{a}_{j}^{\boldsymbol{T}} \boldsymbol{X}\right)\right)\left(\boldsymbol{a}_{\boldsymbol{j}}^{\boldsymbol{T}} \boldsymbol{X}-E\left(\boldsymbol{a}_{j}^{\boldsymbol{T}} \boldsymbol{X}\right)\right)^{T}\right] \\
& =E\left[\left(\boldsymbol{a}_{j}^{\boldsymbol{T}} \boldsymbol{X}-\boldsymbol{a}_{\boldsymbol{j}}^{\boldsymbol{T}} E(\boldsymbol{X})\right)\left(\boldsymbol{a}_{\boldsymbol{j}}^{\boldsymbol{T}} \boldsymbol{X}-\boldsymbol{a}_{\boldsymbol{j}}^{\boldsymbol{T}} E(\boldsymbol{X})\right)^{T}\right] \\
& =E\left[\left(\boldsymbol{a}_{j}^{\boldsymbol{T}} \boldsymbol{X}-\boldsymbol{a}_{\boldsymbol{j}}^{\boldsymbol{T}} \boldsymbol{\mu}\right)\left(\boldsymbol{a}_{\boldsymbol{j}}^{\boldsymbol{T}} \boldsymbol{X}-\boldsymbol{a}_{\boldsymbol{j}}^{\boldsymbol{T}} \boldsymbol{\mu}\right)^{T}\right] \\
& =E\left[\left(\boldsymbol{a}_{\boldsymbol{j}}^{\boldsymbol{T}} \boldsymbol{X}-\boldsymbol{a}_{\boldsymbol{j}}^{\boldsymbol{T}} \boldsymbol{\mu}\right)\left(\boldsymbol{X}^{\boldsymbol{T}} \boldsymbol{a}_{\boldsymbol{j}}-\boldsymbol{\mu}^{\boldsymbol{T}} \boldsymbol{a}_{\boldsymbol{j}}\right)\right] \\
& =\boldsymbol{a}_{\boldsymbol{j}}^{\boldsymbol{T}} E\left[(\boldsymbol{X}-\boldsymbol{\mu})(\boldsymbol{X}-\boldsymbol{\mu})^{T}\right] \boldsymbol{a}_{\boldsymbol{j}} \\
& =\boldsymbol{a}_{\boldsymbol{j}}^{\boldsymbol{T}} \boldsymbol{\Sigma} \boldsymbol{a}_{\boldsymbol{j}} .
\end{aligned}
$$

Komponen utama ke-j yang merupakan kombinasi linear dari variabel asal yang memaksimalkan var $\left(Q_{j}\right)$ dan tidak berkorelasi dengan komponen utama yang lain. Oleh karena itu, $Q_{j}$ harus memenuhi batasan $\boldsymbol{a}_{j}^{\boldsymbol{T}} \boldsymbol{a}_{j}=$ $1, \boldsymbol{a}_{\boldsymbol{i}}^{\boldsymbol{T}} \boldsymbol{a}_{\boldsymbol{j}}=0 ; i<j$ [12]. Untuk mencari komponen utama pertama, pilih vektor $\boldsymbol{a}_{\mathbf{1}}$ yang memaksimumkan varian komponen utama pertama $\boldsymbol{a}_{1}^{\boldsymbol{T}} \boldsymbol{X}$, yaitu memaksimumkan var $\left(Q_{1}\right)=\boldsymbol{a}_{1}^{\boldsymbol{T}} \boldsymbol{\Sigma} \boldsymbol{a}_{\mathbf{1}}$ dengan kendala $\boldsymbol{a}_{\mathbf{1}}^{\boldsymbol{T}} \boldsymbol{a}_{\mathbf{1}}=1$. Pendekatan standarnya adalah dengan teknik pengganda Lagrange atau dalam hal ini akan memaksimumkan fungsi $f\left(\boldsymbol{a}_{\mathbf{1}}\right)=\boldsymbol{a}_{\mathbf{1}}^{\boldsymbol{T}} \boldsymbol{\Sigma} \boldsymbol{a}_{\mathbf{1}}$ dengan kendala $\boldsymbol{a}_{\mathbf{1}}^{\boldsymbol{T}} \boldsymbol{a}_{\mathbf{1}}=1$. Maka fungsi objektif dari permasalahan ini adalah:

$$
\max f\left(\boldsymbol{a}_{1}\right)=\max \left\{\boldsymbol{a}_{1}^{T} \boldsymbol{\Sigma} \boldsymbol{a}_{1}-\lambda\left(\boldsymbol{a}_{1}^{T} \boldsymbol{a}_{1}-1\right)\right\},
$$

dimana $\lambda$ adalah pengganda Lagrange. Maka dari penyelesaian pemaksimuman fungsi objektif di atas dapat diperoleh bahwa var $\left(Q_{1}\right)=\lambda$; yaitu nilai eigen dari matriks kovarian $\boldsymbol{\Sigma}$; dan $\boldsymbol{a}_{\mathbf{1}}$ merupakan vektor eigen dari matriks kovarian $\boldsymbol{\Sigma}$ yang berpadanan dengan nilai eigen $\lambda$. Karena permasalahan dalam pembentukan komponen utama pertama adalah memaksimumkan variannya, maka vektor eigen $\boldsymbol{a}_{\mathbf{1}}$ dari $\boldsymbol{\Sigma}$ yang dipilih adalah yang berpadanan dengan nilai eigen terbesar pertama.

Seperti yang telah dinyatakan di atas, dapat ditunjukkan bahwa komponen utama kedua $\left(Q_{2}\right)$, ketiga $\left(Q_{3}\right)$, keempat $\left(Q_{4}\right), \ldots\left(Q_{j}\right)$, maka vektor eigen $\boldsymbol{a}_{1}, \boldsymbol{a}_{2}, \ldots, \boldsymbol{a}_{\boldsymbol{p}}$ adalah vektor eigen dari matriks kovarian $\boldsymbol{\Sigma}$ yang berpadanan dengan nilai eigen terbesar selanjutnya $\lambda_{2}, \lambda_{3}, \lambda_{4}, \ldots, \lambda_{p}$ dan $\operatorname{var}\left(\boldsymbol{a}^{T} \boldsymbol{X}\right)=\lambda_{j}$, untuk $j=1,2, \ldots, p$. Pada analisis komponen utama (AKU) robust, matriks kovarian robust MCD digunakan untuk pembentukan komponen-komponen utama. Pada prinsipnya metode MCD adalah mencari subsampel yang anggotanya sebanyak $h$ elemen dari matriks data dengan $h$ merupakan bilangan bulat terkecil dari $\frac{n+k+1}{2}$. Misalkan subsampel itu adalah $H_{1}$ maka terdapat sebanyak $C_{h}^{n}$ kombinasi yang harus ditemukan untuk mendapatkan dugaan vektor rataan dan matriks kovarian. Apabila $n$ yang digunakan kecil, pendugaan MCD mudah dan relatif lebih cepat untuk ditemukan. Tetapi, apabila $n$ besar, maka akan banyak kombinasi subsampel yang diperlukan 
untuk mendapatkan pendugaan MCD tersebut. Untuk mengatasi keterbatasan ini, maka digunakan pendekatan FAST-MCD yang dikembangkan oleh Rousseeuw dan Van Driessen [6].

Misalkan terdapat $\boldsymbol{X}=\left\{\mathbf{x}_{1}, \mathbf{x}_{2}, \ldots, \mathbf{x}_{k}\right\}$ merupakan himpunan vektor-vektor pengamatan sejumlah $n$ dengan $k$ variabel. Misalkan $H_{1} \subset\{1,2, \ldots, n\}$ dengan $\left|H_{1}\right|=h$, maka berdasarkan Persamaan (4)-(5) vektor rata-rata dan matriks kovarian MCD secara berturut-turut diberikan oleh:

$$
\begin{gathered}
\overline{\boldsymbol{X}}_{M C D 1}=\frac{1}{h} \sum_{i \in H} \boldsymbol{x}_{\boldsymbol{i}} \\
\boldsymbol{S}_{M C D 1}=\frac{1}{h} \sum_{i \in H}\left[\boldsymbol{x}_{\boldsymbol{i}}-\overline{\boldsymbol{X}}_{M C D}\right]\left[\boldsymbol{x}_{\boldsymbol{i}}-\overline{\boldsymbol{X}}_{M C D}\right]^{T}
\end{gathered}
$$

Jika $\operatorname{det}\left(\boldsymbol{S}_{\mathbf{1}}\right) \neq 0$, maka definisikan jarak robust seperti pada Persamaan (6):

$$
R D_{i}=\sqrt{\left(\boldsymbol{x}_{i}-\overline{\boldsymbol{X}}_{M C D 1}\right)^{T} \boldsymbol{S}_{M C D 1}^{-1}\left(\boldsymbol{x}_{i}-\overline{\boldsymbol{X}}_{M C D 1}\right)},
$$

dengan $i=1,2, \ldots, n$. Kemudian mengurutkan nilai $R D$ mulai dari yang terkecil hingga terbesar. Selanjutnya ambil $H_{2}$ sejumlah $h$ pengamatan dengan jarak terkecil kemudian hitung $\overline{\boldsymbol{X}}_{M C D 2}$ dan $\boldsymbol{S}_{M C D 2}$ dari himpunan $H_{2}$.

Penjelasan MCD mensyaratkan $\operatorname{det}\left(\boldsymbol{S}_{M C D 1}\right) \neq 0$, karena jika $\operatorname{det}\left(\boldsymbol{S}_{M C D 1}\right)=0$ maka nilai objektif minimum untuk mendapatkan determinan terkecil telah ditemukan. Proses pada metode MCD akan berhenti jika ditemukan himpunan bagian yang konvergen yaitu $d\left(\boldsymbol{S}_{i+1}\right)=\operatorname{det}\left(\boldsymbol{S}_{\boldsymbol{i}}\right)$. Dengan demikian pilih subsampel H yang memiliki nilai determinan matriks kovarians terkecil. Kemudian dari subsampel yang terpilih akan dicari nilai $\overline{\boldsymbol{X}}_{M C D}$ dan $\boldsymbol{S}_{M C D}$. Berdasarkan hal tersebut, maka untuk AKU robust akan diperoleh vektor eigen dari matriks kovarian MCD yang berpadanan dengan nilai eigen terbesar pertama dari matriks kovarian MCD.

Pada paper ini hanya menggunakan satu komponen utama, sehingga pada langkah selanjutnya akan diregresikan antara komponen utama tersebut dengan variabel tak bebas Y. Dengan menggunakan metode LTS diperoleh nilai koefisien regresi $\hat{\beta}_{0}$ dan $\hat{\beta}_{1}$.

Penduga LTS diperoleh dengan mempertimbangkan jumlah kuadrat galat:

$$
J K G=\sum_{i=1}^{h} \varepsilon_{i}^{2}=\sum_{i=1}^{h}\left(y_{i}-\beta_{0}-\beta_{1} Q_{i}\right)^{2}
$$

Untuk mendapatkan nilai $\beta_{0}$ dan $\beta_{1}$ pada Persamaan (10) maka $J K G$ diturunkan terhadap $\beta_{0}$ dan $\beta_{1}$ kemudian menyamakannya dengan nol. Jika $J K G$ diturunkan terhadap $\beta_{0}$ maka diperoleh:

$$
\begin{gathered}
\frac{\partial J K G}{\partial \beta_{0}}=-2 \sum_{i=1}^{h}\left(y_{i}-\beta_{0}-\beta_{1} Q_{i}\right)=0 \\
\sum_{i=1}^{h} y_{i}-h \beta_{0}-\beta_{1} \sum_{i=1}^{h} Q_{i}=0 \\
\beta_{0}=\frac{\sum_{i=1}^{h} y_{i}-\beta_{1} \sum_{i=1}^{h} Q_{i}}{h}
\end{gathered}
$$

Tulis $\bar{y}=\frac{\sum_{i=1}^{h} y_{i}}{h}$ dan $\bar{Q}=\frac{\sum_{i=1}^{h} Q_{i}}{h}$ maka diperoleh:

$$
\hat{\beta}_{0}=\bar{y}-\hat{\beta}_{1} \bar{Q}
$$

Selanjutnya jika $J K G$ diturunkan terhadap $\beta_{1}$ dan disamakan dengan nol maka diperoleh

Dengan cara yang sama dapat diperoleh:

$$
\frac{\partial J K G}{\partial \beta_{1}}=-2 \sum_{i=1}^{h}\left(y_{i}-\beta_{0}-\beta_{1} Q_{i}\right) Q_{i}=0 .
$$

$$
\hat{\beta}_{1}=\frac{h \sum_{i=1}^{h} y_{i} Q_{i}-\sum_{i=1}^{h} y_{i} \sum_{i=1}^{h} Q_{i}}{h \sum_{i=1}^{h} Q_{i}{ }^{2}-\sum_{i=1}^{h}\left(Q_{i}\right)^{2}} .
$$

Jadi, $\hat{\beta}_{0}$ dan $\hat{\beta}_{1}$ pada Persamaan (11) dan Persamaan (12) merupakan penduga bagi nilai koefisien RKU robust yaitu menggunakan metode MCD-LTS. 


\subsection{Hasil Simulasi}

Berikut ini kami sajikan nilai rata-rata bias dan MSE hasil simulasi dengan ulangan sebanyak 1000 kali.

Tabel 1. Rata-Rata Bias dan MSE Pendugaan Koefisien Regresi Komponen Utama

\begin{tabular}{|c|c|c|c|c|c|}
\hline \multirow[b]{2}{*}{$\mathbf{n}$} & \multirow{2}{*}{$\begin{array}{c}\text { Pencilan } \\
(\%)\end{array}$} & \multicolumn{2}{|c|}{ Rata-Rata Bias } & \multicolumn{2}{|c|}{ Rata-Rata MSE } \\
\hline & & $\begin{array}{c}\text { RKU } \\
\text { Klasik } \\
\end{array}$ & $\begin{array}{c}\text { RKU } \\
\text { Robust }\end{array}$ & $\begin{array}{c}\text { RKU } \\
\text { Klasik } \\
\end{array}$ & $\begin{array}{c}\text { RKU } \\
\text { Robust } \\
\end{array}$ \\
\hline \multirow{5}{*}{20} & 5 & 2,2985 & 0,2673 & 5,3236 & 0,2301 \\
\hline & 10 & 3,557 & 0,2459 & 14,7344 & 0,148 \\
\hline & 15 & 4,8047 & 0,2688 & 30,3489 & 0,1727 \\
\hline & 20 & 6,0513 & 0,5145 & 52,2118 & 0,4211 \\
\hline & 25 & 7,3025 & 0,5111 & 80,3393 & 0,4713 \\
\hline \multirow{5}{*}{60} & 5 & 2,2633 & 0,5075 & 5,1785 & 0,4866 \\
\hline & 10 & 3,5315 & 0,5388 & 14,6277 & 0,4946 \\
\hline & 15 & 4,7819 & 0,4392 & 30,2556 & 0,3221 \\
\hline & 20 & 6,0328 & 0,3416 & 52,1328 & 0,1981 \\
\hline & 25 & 7,2864 & 0,2159 & 80,2717 & 0,0882 \\
\hline \multirow{5}{*}{100} & 5 & 2,2817 & 0,1531 & 5,254 & 0,0474 \\
\hline & 10 & 3,5458 & 0,1026 & 14,6875 & 0,0284 \\
\hline & 15 & 4,7951 & 0,0435 & 30,3097 & 0,02 \\
\hline & 20 & 6,0449 & 0,2353 & 52,1833 & 0,0893 \\
\hline & 25 & 7,2975 & 0,238 & 80,3188 & 0,0925 \\
\hline \multirow{5}{*}{200} & 5 & 2,2725 & 0,1806 & 5,2161 & 0,0641 \\
\hline & 10 & 3,522 & 0,0525 & 14,5889 & 0,0121 \\
\hline & 15 & 4,7766 & 0,0837 & 30,2328 & 0,0124 \\
\hline & 20 & 6,0278 & 0,1374 & 52,1125 & 0,0287 \\
\hline & 25 & 7,2747 & 0,1429 & 80,2252 & 0,0224 \\
\hline
\end{tabular}

Pada Tabel 1 terlihat bahwa nilai rata-rata bias dan MSE dari data mengandung pencilan 5\% - 25\% yang dihasilkan dari metode RKU klasik lebih besar dibandingkan RKU robust. Pada RKU klasik, terlihat juga bahwa setiap penambahan persentase dalam satu ukuran sampel maka selalu terjadi peningkatan nilai rata-rata bias dan MSE, bahkan diperoleh nilai rata-rata bias dan MSE > 1 di masing-masing persentase pencilan dan ukuran sampel tersebut. Hal ini dapat diartikan nilai dugaan koefisien RKU klasik semakin buruk. Sedangkan pada RKU robust rata-rata bias dan MSE yang dihasilkan selalu lebih kecil atau di bawah nilai rata-rata bias dan MSE RKU klasik yaitu nilai rata-rata bias dan MSE $<1$ di masing-masing persentase pencilan dan ukuran sampel tersebut.

Berdasarkan nilai rata-rata bias dan MSE dengan ukuran sampel yaitu 20, 60, 100, dan 200 serta persentase pencilan yaitu $5 \%, 10 \%, 15 \%, 20 \%$, dan $25 \%$ yang disajikan pada Tabel 1, maka akan diperoleh grafik perbandingan dari metode RKU klasik dan robust sebagai berikut: 


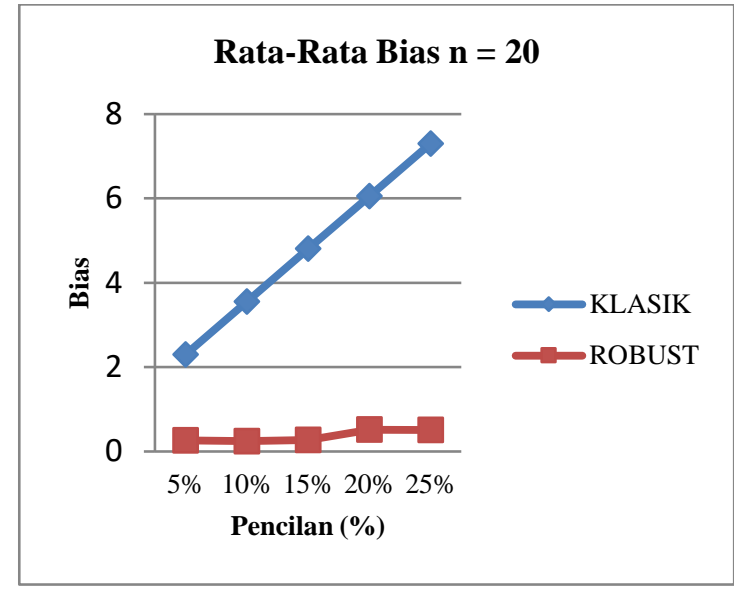

Gambar 1. Grafik Rata-Rata Bias untuk n = 20.

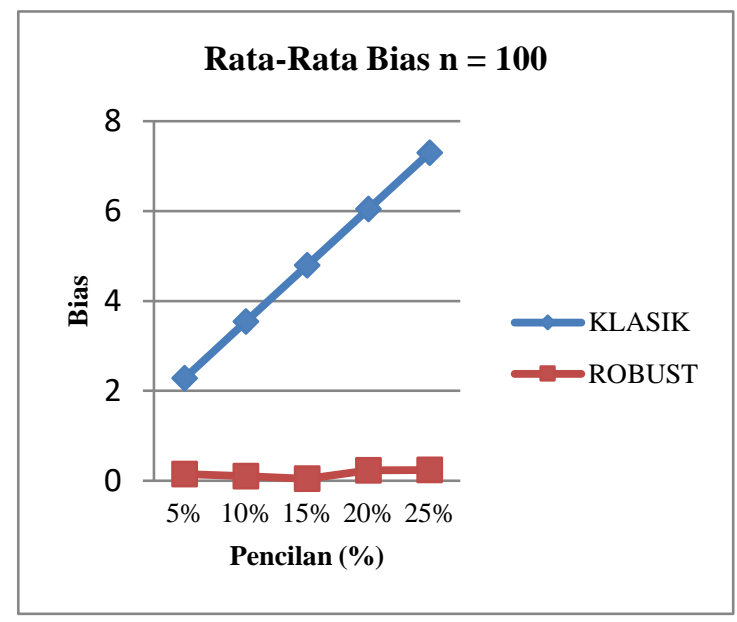

Gambar 3. Grafik Rata-Rata Bias untuk $n=100$.

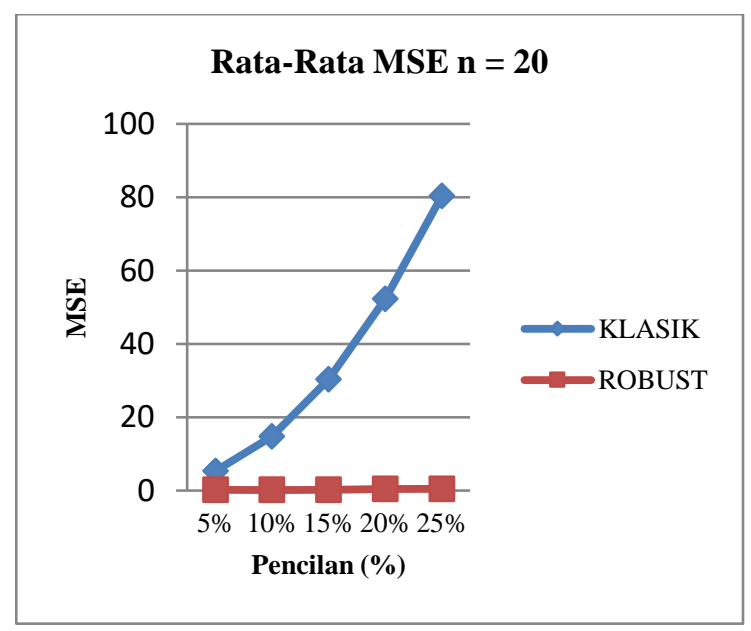

Gambar 5. Grafik Rata-Rata MSE untuk $n=20$. Gambar 6. Grafik Nilai Rata-Rata MSE untuk $n=60$.

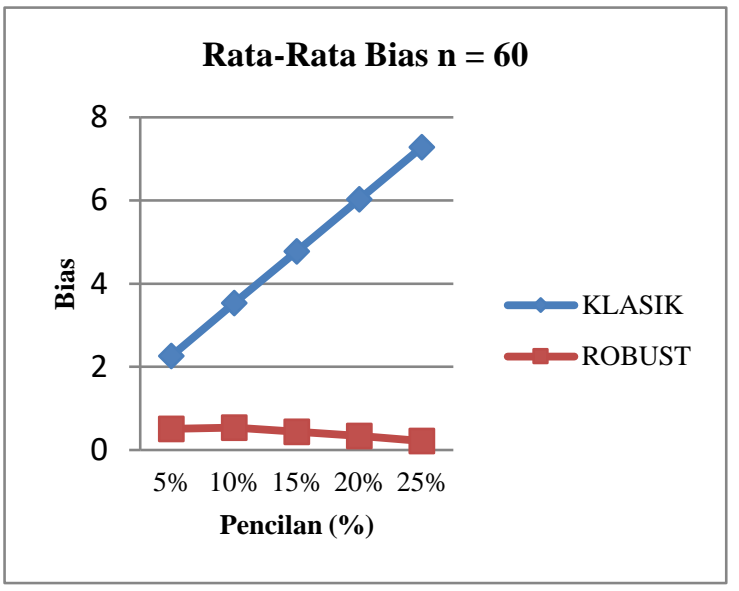

Gambar 2. Grafik Rata-Rata Bias untuk n = 60.

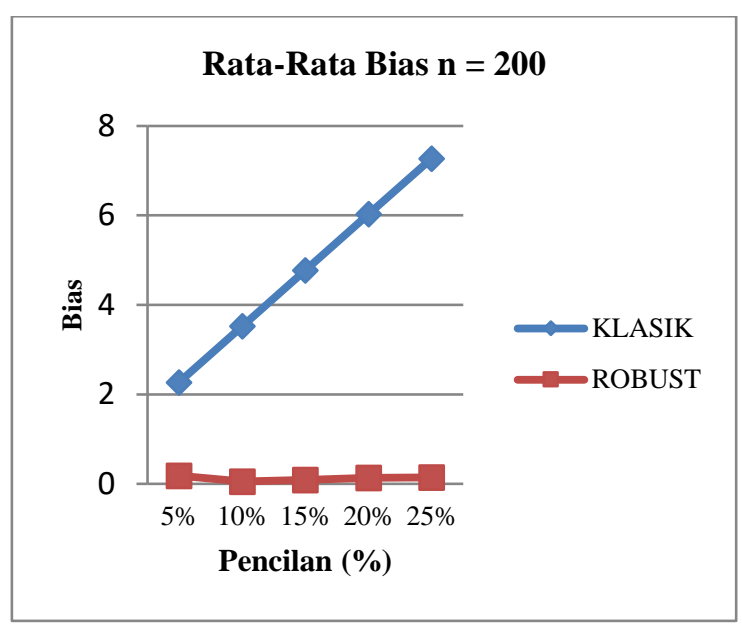

Gambar 4. Grafik Rata-Rata Bias untuk $\mathbf{n}=\mathbf{2 0 0}$.

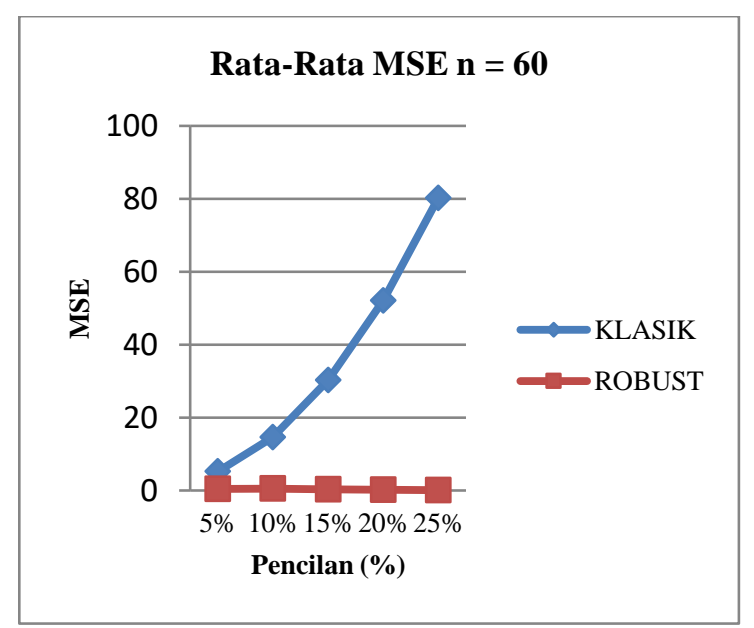




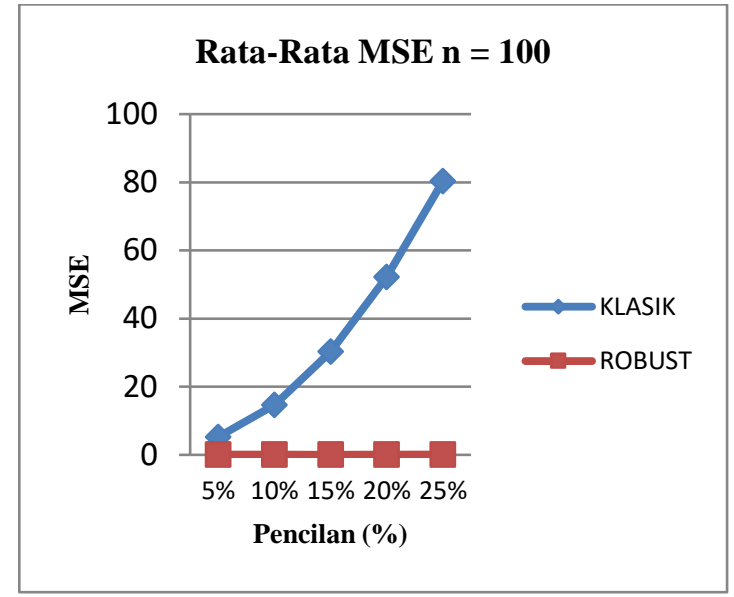

Gambar 7. Grafik Rata-Rata MSE untuk n = 100.

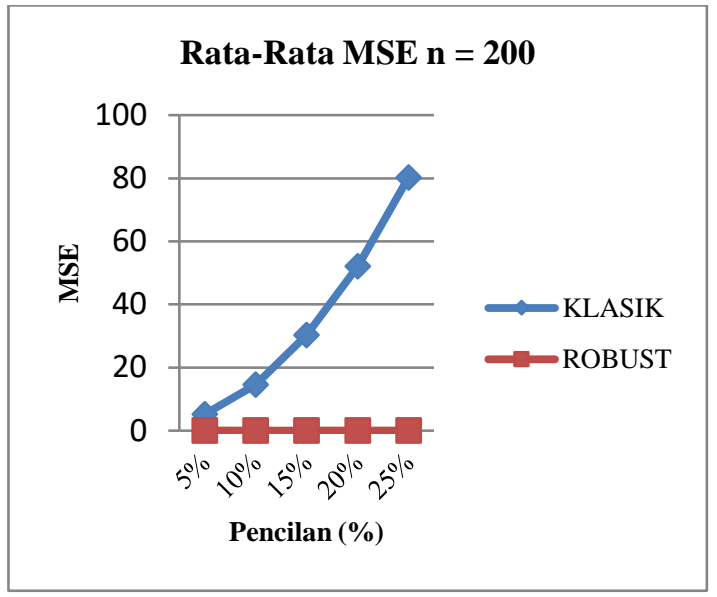

Gambar 8. Grafik Rata-Rata MSE untuk n = 200.

Berdasarkan Gambar 1 - Gambar 4, terlihat bahwa letak garis nilai rata-rata bias RKU klasik dengan ukuran sampel 20,60,100, 200 berada di atas garis nilai rata-rata bias RKU robust. Gambar 1 - Gambar 4 juga terlihat bahwa titik-titik yang disambungkan garis untuk nilai rata-rata bias pada RKU klasik di setiap persentase pencilan selalu naik secara konstan sedangkan pada RKU robust titik-titik yang disambungkan garis untuk nilai rata-rata bias di setiap persentase pencilan tidak secara konstan naik atau turun. Selanjutnya, berdasarkan Gambar 5 - Gambar 8 terlihat bahwa letak garis nilai rata-rata MSE RKU klasik dengan masing-masing ukuran sampel tersebut berada di atas garis nilai rata-rata MSE RKU robust. Gambar 5 - Gambar 8 juga terlihat bahwa titik-titik yang disambungkan garis untuk nilai rata-rata MSE pada RKU klasik di setiap persentase pencilan selalu naik secara konstan yaitu berkisar dari angka $>5$ hingga angka $\geq 80$ sedangkan pada RKU robust titiktitik yang disambungkan garis untuk nilai rata-rata MSE di setiap persentase pencilan tidak secara konstan naik atau turun, dapat dikatakan hanya di sekitar angka $<0,5$.

\section{Kesimpulan}

Berdasarkan hasil dan pembahasan, maka diperoleh kesimpulan sebagai berikut:

1. Analisis Komponen Utama Robust dapat dilakukan dengan menggunakan matriks kovarian robust MCD dan metode regresi robust LTS dengan penduga nilai koefisien RKU robust sebagai berikut:

$$
\begin{array}{ll}
\text { dimana, } & \\
Q & =\text { Komponen utama. } \\
h & =\text { Banyaknya anggota dalam subsampel terbaik. }
\end{array}
$$$$
\begin{aligned}
& \hat{\beta}_{0}=\frac{\sum_{i=1}^{h} y_{i}-\beta_{1} \sum_{i=1}^{h} Q_{i}}{h} \\
& \hat{\beta}_{1}=\frac{h \sum_{i=1}^{h} y_{i} Q_{i}-\sum_{i=1}^{h} y_{i} \sum_{i=1}^{h} Q_{i}}{h \sum_{i=1}^{h} Q_{i}{ }^{2}-\sum_{i=1}^{h}\left(Q_{i}\right)^{2}}
\end{aligned}
$$

2. Pada hasil simulasi diperoleh bahwa pada suatu ukuran sampel dengan presentase pencilan 5\%-25\%, nilai rata-rata bias dan MSE metode RKU klasik selalu naik secara konstan disetiap penambahan presentase pencilan sedangkan metode RKU robust diperoleh nilai rata-rata bias yang lebih kecil dibandingkan RKU klasik. Hal ini menunjukkan bahwa metode RKU robust merupakan metode yang kekar terhadap pencilan, sedangkan metode RKU klasik sangat sensitif terhadap danya pencilan. Dengan demikian maka RKU robust menggunakan MCD-LTS memberikan hasil yang baik dan merupakan metode efektif dan efisien dalam mengatasi masalah multikolinearitas dan pencilan. 


\section{Daftar Pustaka:}

[1] Draper, N.R. dan Smith, H. 2011. Applied Regression Analysis, 3rd Edition, India: Wiley.

[2] Notiragayu dan Nisa, K. 2008. Analisis Regresi Komponen Utama Robust untuk Data mengandung Pencilan. Jurnal Sains MIPA. 14 : 1 45-50.

[3] Abdel Bary, M.N. 2017. Robust Regression Diagnostic for Detecting and Solving Multicollinearity and Outlier Problems: Applied Study by Using Financial Data. Applied Mathematical Sciences. 11 : $13601-622$.

[4] Agarwal, A., Shah, D., Shen, D. dan Song, D. 2020. On Robustness of Principal Component Regression. ArXiv: 1902.10920v7 1-57.

[5] Oh, T-H., Matsushita, Y., Kweon, I.S. dan Wipf, D. 2016. A Pseudo-Bayesian Algorithm for Robust PCA. Proceeding of 30th Conference on Neural Information Processing Systems (NIPS). Barcelona, Spain.

[6] Nisa, K., Herawati, N., Setiawan, E., Nusyirwan. (2006). Robust Principal Component Analysis using the Minimum Covariance Determinant Estimator. Proceeding of International Conference on Mathematics and Natural Sciences (ICMNS) : 789-792.

[7] Rousseeuw, P.J. dan Van Driessen, K. 1999. A Fast Algorithm for the Minimum Covariance Determinant Estimator. Technometrics. 41 : 3 212-223.

[8] Dayanti, N. P., Suciptawati, N.L. dan Susilawati, M. 20616. Penerapan Bootstrap dalam Metode Minimum Covariance Determinant (MCD) dan Least Median Square (LMS) pada Analisis Regresi Linear Berganda., E-Jurnal Matematika. 5 : 1 22-26.

[9] Nisa, K. 2006. Analisis Regresi Robust Menggunakan Metode Least Trimmed Square untuk Data Mengandung Pencilan. Jurnal Ilmiah MIPA. IX : 2 1-9.

[10] Chen, C. 2002. Robust Regression and Outlier Detection with the ROBUSTREG Procedure. Proceeding of the $27^{\text {th }}$ SAS User Group International (SUGI) Conference. Cary, NC: SAS Institute Inc. 1-13.

[11] McDonald, G.C. dan Galarneau, D.I. 1975. A Monte Carlo Evaluation of Some Ridge-Type Estimators. Journal of American Statistical Association. 70 407-416.

[12] Jolliffe, I.T. 2002. Principal Component Analysis second edition. Springer.. 